\title{
INCREASING THE EFFICIENCY OF THE ROOF PURLIN SYSTEM
}

\author{
Kupchenko Y.V., PhD., Assistant Professor, \\ steelconpro@gmail.com, ORCID: 0000-0003-1480-6884 \\ Singayevsky P. M., PhD., Assistant Professor, \\ mdipk@ukr.net, ORCID: 0000-0003-1268-414X \\ Lesechko O.V., PhD., Assistant Professor, \\ a.lesechko@ukr.net, ORCID:0000-0002-2352-6174 \\ Konstantinov P.V., PhD., \\ Konstantinov31@mail.ru, ORCID: 0000-0002-8478-2980 \\ Odessa State Academy of Civil Engineering and Architecture
}

\begin{abstract}
In the article, the authors consider one of the ways to solve the problem of reducing metal consumption and increasing the efficiency of metal structures by choosing an effective static scheme. The choice of the appropriate scheme is carried out for the most common elements of metal structures - beams, which also include roof purlins.

To cover the industrial building of the seaport, discontinuous and continuous stringer systems are being developed and their efficiency is analyzed in terms of metal consumption and labor intensity.
\end{abstract}

Keywords: truss, covering, beam, purlin, discontinuous scheme, continuous scheme

Introduction. One of the important tasks in the field of improving building structures, including steel ones, is to reduce their material consumption, which can be achieved on the basis of further study of the actual operation of structures, improvement of design schemes, development of the structural form, the use of high-strength steels, the use of effective types of cross-sections of elements. Steel Structural Design Codes [1] recommend «to choose the optimal technical and economic indicators of structural schemes of buildings; apply progressive constructions...; to provide manufacturability and the least complexity of manufacturing structures; to apply designs providing manufacturability and the least complexity of installation».

The problem of reducing metal consumption will never lose its acuteness, since prices for raw materials and energy are constantly increasing, and the Earth's interior is gradually depleting. This prompts to constantly develop measures to save metal and consider it one of the main tasks of scientific and technological progress in metal construction.

To cover the industrial building of the seaport, continuous cut and discontinuous systems are being developed and their efficiency is analyzed in terms of metal consumption and labor intensity.

Analysis of recent research and publications. Among the many ways to solve the problem of reducing metal consumption and increasing the efficiency of metal structures is the possibility of choosing effective schemes, in particular continuous ones, in the most common elements of metal structures - beams, which include purlins. These issues were considered in works $[2,3,4,5]$ and others. Continuous systems have long attracted the attention of scientists and metal-building engineers. A large amount of material has been accumulated about these structures, on the basis of which the advantages and disadvantages of continuous beam structures can be distinguished. The advantages of continuous structures include: 1) a decrease in metal consumption compared to discontinuous structures under the same operating conditions, which is a consequence of a more favorable distribution of bending moments in beams. This is especially important for long lengths and significant loads, when the mass of the supporting structure makes up a significant proportion of the entire set of loads, which is manifested in the structures of building coatings; 2) less deformability of the structure due to static indeterminacy with the same dimensions and cross-sectional size in 
comparison with similar discontinuous structures. This advantage makes it possible to expand the field of application of steels of increased and high strength, when restrictions on deformability force them to reject them in discontinuous structures; 3 ) reduction or absence of a break in the deformation line on intermediate supports; 4) greater efficiency of using the elastoplastic stage of steel work in continuous beams than in discontinuous ones. The bearing capacity of continuous beams increases not only as a result of the development of limited plastic deformations, but also as a result of the redistribution of the bending moment; 5) the possibility in some cases of lifting during the installation of enlarged structures that overlap several spans at once.

Continuous structures also have some disadvantages: 1) the possibility of the appearance of an uncontrolled stress state due to uneven settlement of the bases, as a result of which their reliability is fundamentally reduced; 2) the accumulation of thermal deformations, larger in magnitude than in discontinuous structures. This disadvantage is especially noticeable in open long structures subjected to the action of temperature at its large drops; 3) the difference in the values of the support reactions on the extreme and intermediate supports; 4) an increase in some cases of the specific labor intensity of the manufacture of structures, as a result of the implementation of additional elements that ensure the continuity of beams; 5) some complication of installation when creating continuity after lifting structures, when the installation is carried out span-by-span. In this case, the labor constant of installation may increase, since the labor intensity of work, especially welding, at the top is much higher than the labor intensity of the same work at the bottom. The first of these disadvantages is the most significant. The rest disadvantages are not fundamental. And yet, continuous beam structures have not had proper distribution.

The aim of the work is to determine the effectiveness of continuous purlin with a different number of spans and the corresponding provision of the least laboriousness of manufacture, creation of continuity and installation.

Research results. An industrial building, for which discontinuous stringer and continuous coating scheme is being developed, is a single-span one-story $138 \mathrm{~m}$ long, a span of $30 \mathrm{~m}$, a pitch of trusses of $6 m$ (Fig. 1).

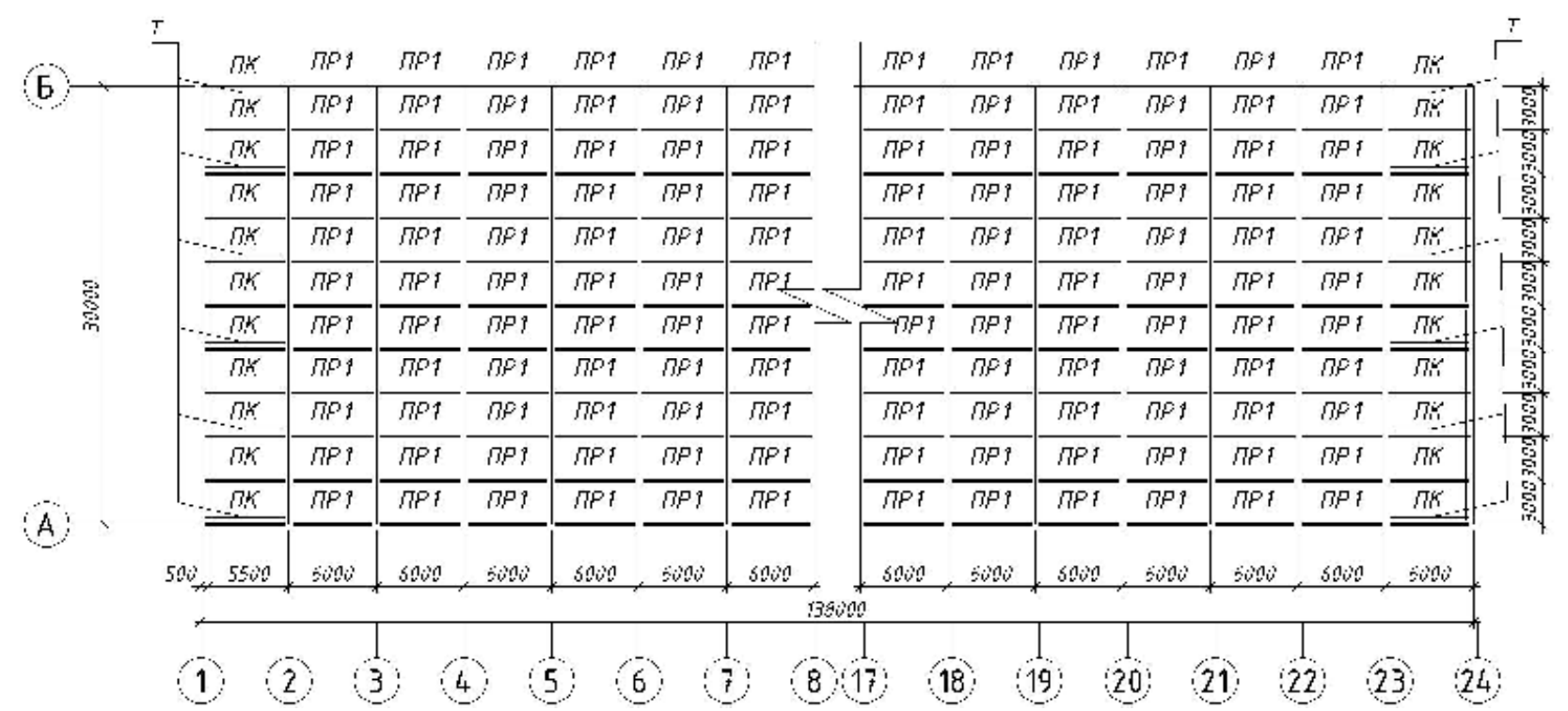

Fig. 1. Marking scheme of discontinuous purlins

- To determine the effectiveness of the use of continuous purlins, the selection of sections of a discontinuous purlin (Fig. 1) and a continuous one was performed with a different number of continuous spans (Fig. 2, 3).

- The continuous purlin is calculated as a single-span beam merely supported on the upper chords of the trusses. The calculation is carried out for uniaxial bending, since the slope of the coating 
is $1.5 \%<2 \%$. The cross-section of the purlin was selected from a rolled channel with parallel flange faces No. 18П (DSTU 3436-96).

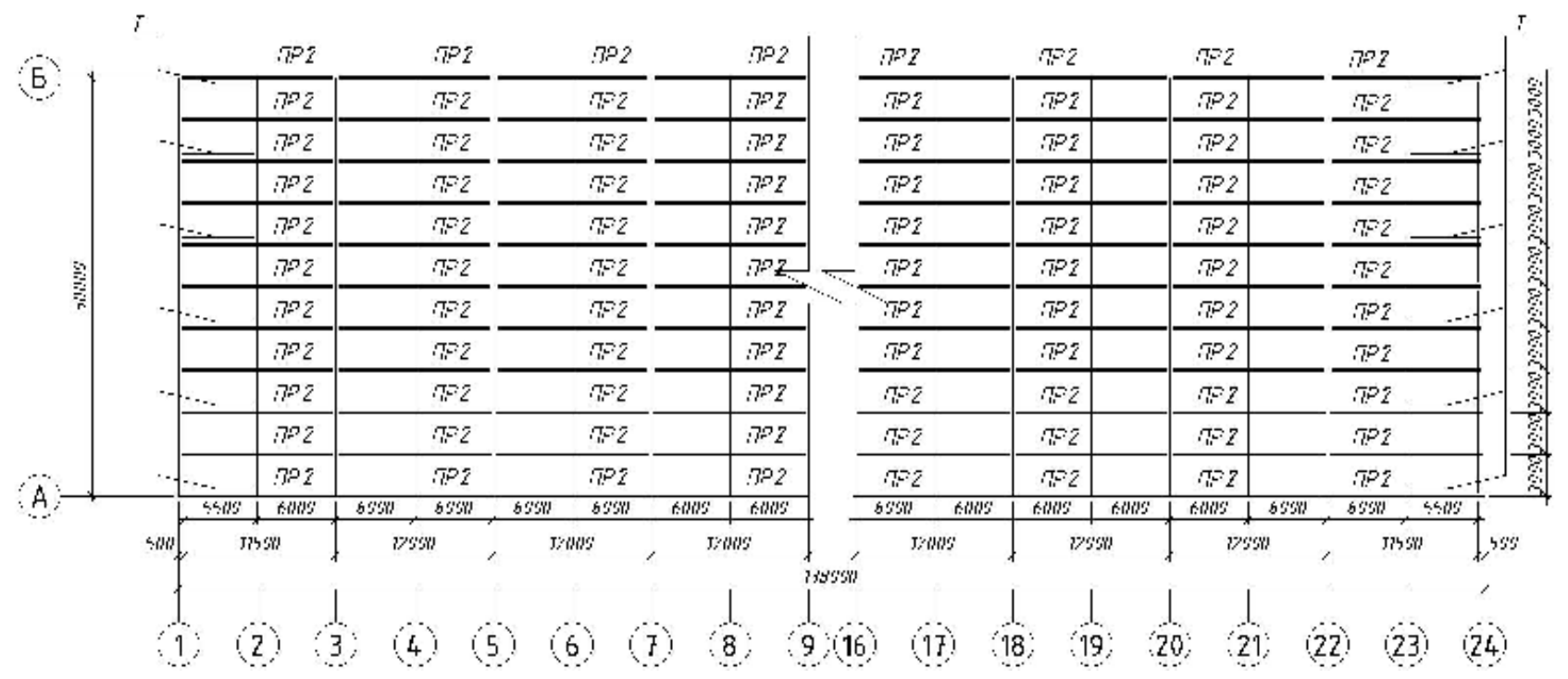

Fig. 2. Marking scheme for two-span continuous purlins

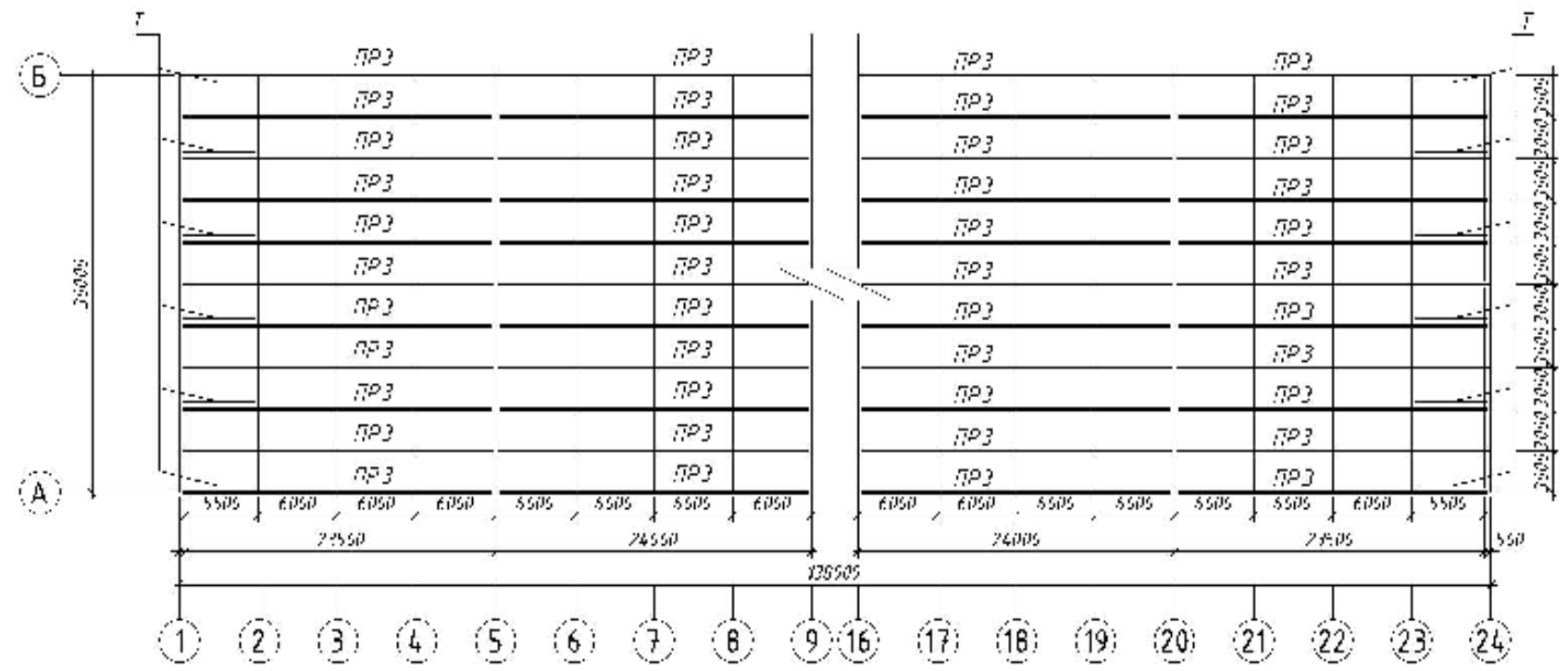

Fig. 3. Marking scheme for four-span continuous purlins

Sections of a continuous two-span purlin (Fig. 2) and a continuous four-span purlin (Fig. 3) were selected from a rolling channel No. 14P. Saving steel per one running meter of a purlin in comparison with a discontinuous scheme is $2.1 \mathrm{~kg}$.

When selecting a section of a continuous purlin, the possibility of the development of limited plastic deformations in the section and the corresponding partial redistribution of the support and span moments (as for sections of the 2nd class by the type of stress-strain state [1]) were taken into account. In accordance with this and the requirements of [1], the calculated value of the bending moment $M$ was determined by the formula:

$$
M=\alpha \cdot M_{\max }
$$

where $M_{\max }$ - is the largest bending moment in a span or on a support, found from the calculation of a continuous purlin under the condition of elastic work of steel.

Moment redistribution coefficient $\alpha$ : 


$$
\alpha=0.5 \cdot\left(1+\frac{M_{e f}}{M_{\max }}\right)
$$

The numerical value of the conditional bending moment $M_{e f}$ was taken equal to the larger of the two values:

$$
M_{e f}=\frac{M_{1}}{1+\frac{a}{l}} ; \quad M_{e f}=0.5 \cdot M_{2}
$$

where $M_{1}$ - bending moment in the outermost span, calculated as for a freely supported single-span beam;

$a$ - the distance from the section, where the bending moment $M_{1}$, acts, to the outer support;

$M_{2}$ - maximum bending moment in an intermediate span, calculated as for a freely supported singlespan beam;

$l$ - end span length.

It is very important for continuous purlins to design a simple knot that will provide continuity. It should not be complicated and with a minimum labor intensity of the device, since these works are performed by the installer at a height, on the coating of the building being constructed. From this point of view, the most rational is a two-span continuous purlin (according to the scheme in Fig. 2). The length of each span of the purlin is $6 \mathrm{~m}$, the total length of the purlin is $12 \mathrm{~m}$ - corresponds to the standard size of the rolled product. Such a purlin will be completely prepared for installation in the factory and its installation is carried out with a single mark drawing on the trusses located with a pitch of $6 \mathrm{~m}$. Fastening is carried out, as for discontinuous purlins, on bolts, through a shorty from an unequal angle welded to the upper chords of the trusses. But in this case, there is no mounting gap $(10 \ldots 20 \mathrm{~mm})$ on the middle support of a two-span continuous purlin, as in the case of a $6 \mathrm{~m}$ long discontinuous purlin.

- For continuous purlins with more than two spans, creating a continuous line is already a more difficult task. The following knot solution is proposed: firstly, along the length of the continuous purlin, the knot must be located in the zone of action of zero bending moments, where the value of the force is zero or close to it; further, between the channels at the junction, we leave a gap of $50 \mathrm{~mm}$, and on the side of the wall of the joined channels we install an overlay (with a length of $0.1 \cdot l_{\text {purlin }}=$ $0.1 \cdot 6=0.6 \mathrm{~m}$, where $l_{\text {purlin }}=6 \mathrm{~m}$ is the span of the purlin) from the channel of the same section, located with shelves in the opposite direction; we pre-fix the abutting channels and the pad using two bolts of normal accuracy (we place them in the middle of the wall in height), and then we make the connection by welding; the upper weld seam should be internal, it should not protrude above the plane of the upper flanges of the channels, so as not to interfere with the subsequent fastening of the sheets of the steel profiled flooring - for this, before installation, the feather edges of the channels of the purlins and the overlays along the length of the joint are beveled. This unit is simple, technologically convenient in execution and has low labor intensity.

- Also, for a four-span purlin, in the presence of two twelve-meter mark drawings, you can make a joint on the middle support, but in this case we accept a longer pad - $1.2 \mathrm{~m}$ (the pad protrudes beyond the axis of the joint on each side by a distance of $0.1 \cdot l_{\text {purlin }}=0.1 \cdot 6=0.6 \mathrm{~m}$ ).

Conclusion: Replacing discontinuous purlins with continuous ones leads to significant savings in steel; does not increase the labor intensity of work and even somewhat simplifies installation when using a two-span scheme; increases labor intensity and complicates installation when using multispan schemes.

1. The simplest in terms of labor intensity and execution is the device of a continuous purlin according to a two-span scheme. In this case, it is possible to use rolled product of a standard length $(12 \mathrm{~m})$ and use the same attachment points for the purlins to the upper chords of the trusses, as in the 
discontinuous scheme (in the absence of an installation gap). Saving steel when using a continuous two-span scheme (channel No. 14П, DSTU 3436-96) compared to the discontinuous-section layout of the purlins (channel No. 18П, DSTU 3436-96) is $24 \mathrm{~kg}$ for $6 \mathrm{~m}$ long rolled products. Saving on the entire coating of the projected building (span $30 \mathrm{~m}$, length $138 \mathrm{~m}$, truss spacing $6 \mathrm{~m}$, purlin spacing 3 $m$; Fig. 1, 2), where the number of $6 \mathrm{~m}$ long purlins is 276 pieces: $276 \cdot 24=6624 \mathrm{~kg}$.

2. When using a continuous four-span scheme (Fig. 3), the savings in steel (channel No. 14П) compared to the discontinuous scheme (Fig. 1) of the location of the purlins (channel No. 18П) is also $24 \mathrm{~kg}$ for rolled products with a length of $6 \mathrm{~m}$. In this case, the steel savings for the entire covering of the projected building is also $6624 \mathrm{~kg}$, as when using a two-span continuous scheme, but with a more complex and time-consuming assembly.

3. To cover the projected building, it is recommended to use purlins according to a continuous two-span scheme, which, in comparison with the discontinuous scheme, provides a steel saving of $6624 \mathrm{~kg}$ and does not increase, but even somewhat reduces the labor intensity and complexity of installation due to the use of standard $12 \mathrm{~m}$ long rolled products.

\title{
References
}

[1] DBN V.2.6-198:2014. Stal'nyye konstruktsii. Normy proyektirovaniya [chynni vid 2015-0101]. K.: Minrehion Ukrainy, 2014.

[2] V.O. Permyakov, I.D. Byelov, Metalevi konstruktsiyi fermy, Kyev: KNUBA, 2006.

[3] V.V. Biryulev Metallicheskiye nerazreznyye konstruktsii s regulirovaniyem urovnya opor, Moskva: Stroyizdat, 1984.

[4] V.A. Semko, D.A. Prokhorenko «Analiz konstruktivnykh mer dlya povysheniya nadezhnosti pokrytiy iz legkikh stal'nykh tonkostennykh profiley». Elektronnyy zhurnal «Predotvrashcheniye avariy zdaniy $i$ sooruzheniy», Magnitogorsk, 2011, II quarter.

[5] Newman A. Metal Building Systems Design and Specifications, 2nd edition, - New York: McGraw-Hill, 2003.

\section{ПІДВИЩЕННЯ ЕФЕКТИВНОСТІ ПРОГОНОВОЇ СИСТЕМИ ПОКРИТТЯ}

\author{
Купченко Ю.В., к.Т.н., доцент, \\ steelconpro@gmail.com, ORCID: 0000-0003-1480-6884 \\ Сінгаївський П.М., к.т.н., доцент, \\ mdipk@ukr.net, ORCID: 0000-0003-1268-414X \\ Лесечко О.В., к.ф-м.н., доцент, \\ a.lesechko@ukr.net, ORCID:0000-0002-2352-6174 \\ Константінов П.В., к.Т.н., \\ Konstantinov31@mail.ru, ORCID: 0000-0002-8478-2980 \\ Одеська державна академія будівництва та архітектури
}

Анотація. Одним з важливих завдань в області вдосконалення будівельних конструкцій, у тому числі сталевих, є зниження їх матеріаломісткості, що може бути досягнуте на основі подальшого вивчення дійсної роботи конструкцій, вдосконалення конструктивних i розрахункових схем, розвитку конструктивної форми, застосування високоміцних сталей, використання ефективних типів поперечних перерізів елементів.

Серед багатьох шляхів рішення задачі зниження металоємності і підвищення ефективності металевих конструкцій знаходиться і можливість вибору ефективних схем, 
зокрема нерозрізних, в найбільш поширених елементах металевих конструкцій - балках, до яких відносяться і прогони покриттів.

Для покриття виробничої будівлі морського торгівельного порту розробляється прогонова розрізна і нерозрізна системи і аналізується їх ефективність по металоємності і трудомісткості.

Для визначення ефективності застосування нерозрізних прогонів був виконаний підбір перерізів розрізного прогону і нерозрізного при різній кількості нерозрізних прольотів. Переріз розрізного прогону підібраний з прокатного швелера з паралельними гранями полиць № 18П, перерізи нерозрізного двопролітного прогону і нерозрізного чотирьохпролітного прогону підібрані $з$ прокатного швелера № 14П. Економія сталі на одному погонному метрі нерозрізного прогону в порівнянні з розрізною схемою складає $2.1 \kappa 2$.

При підборі перерізу нерозрізного прогону враховувалася можливість розвитку в перерізі обмежених пластичних деформацій і відповідний частковий перерозподіл опорного і пролітного моментів (як для перерізів 2-го класу за видом напружено-деформованого стану).

Найбільш простим за трудомісткістю і виконанням $є$ влаштування нерозрізного прогону за двопролітною схемою. В цьому випадку для відправної марки можливе використання прокату стандартної довжини (12 м) і застосування таких же вузлів кріплення прогонів до верхніх поясів кроквяних ферм, як при розрізній схемі (за відсутності монтажного зазору). Економія сталі при використанні нерозрізної двопролітної схеми в порівнянні з розрізною схемою розташування прогонів для покриття будівлі, що проектується (проліт $30 \mathrm{M}$, довжина 138 м, крок ферм 6 м, крок прогонів 3 м) складає $6624 \kappa 2$.

При використанні нерозрізної чотирьохпролітної схеми економія сталі в порівнянні 3 розрізною схемою складає також 6624 к2, як при використанні двопролітної нерозрізної схеми, але із більш складнішим і трудомістким вузлом.

Заміна розрізних прогонів покриття досліджуємої будівлі нерозрізними приводить до істотної економії сталі; не підвищує трудомісткість робіт і навіть декілька спрощує монтаж при використанні двопролітної схеми; підвищує трудомісткість робіт і ускладнює монтаж при використанні багатопролітних схем.

Ключові слова: ферма, покриття, балка, прогон, розрізна схема, нерозрізна схема

\title{
ПОВЫШЕНИЕ ЭФФЕКТИВНОСТИ ПРОГОННОЙ СИСТЕМЫ ПОКРЫТИЯ
}

\author{
Купченко Ю.В., к.т.н., доцент, \\ steelconpro@gmail.com, ORCID: 0000-0003-1480-6884 \\ Сингаевский П.М., к.Т.Н., доцент, \\ mdipk@ukr.net, ORCID: 0000-0003-1268-414X \\ Лесечко А.В., к.ф-м.н., доцент, \\ a.lesechko@ukr.net, ORCID:0000-0002-2352-6174 \\ Константинов П.В., к.т.н., \\ Konstantinov31@mail.ru, ORCID: 0000-0002-8478-2980 \\ Одесская государственная академия строительства и архитектуры
}

Аннотация. Одной из важных задач в области совершенствования строительных конструкций, в том числе стальных, является снижение их материалоемкости, что может быть достигнуто на основе дальнейшего изучения действительной работы конструкций, совершенствования конструктивных и расчетных схем, развития конструктивной формы, применения высокопрочных сталей, использование эффективных типов поперечных сечений элементов. 
Среди многих путей решения задачи снижения металлоемкости и повышения эффективности металлических конструкций находится и возможность выбора эффективных схем, в частности неразрезных, в наиболее распространенных элементах металлических конструкций - балках, к которым относятся и прогоны покрытий.

Для покрытия производственного здания морского торгового порта разрабатывается прогонная разрезная и неразрезная системы и анализируется их эффективность по металлоемкости и трудоемкости.

- Для определения эффективности применения неразрезных прогонов был выполнен подбор сечений разрезного прогона и неразрезного при разном количестве неразрезных пролетов. Сечение разрезного прогона подобрано из прокатного швеллера с параллельными гранями полок № 18П, сечения неразрезного двухпролетного прогона и неразрезного четырехпролетного прогона подобраны из прокатного швеллера № 14П. Экономия стали на одном погонном метре неразрезного прогона по сравнению с разрезной схемой составляет 2.1 $\kappa 2$.

При подборе сечения неразрезного прогона учитывалась возможность развития в сечении ограниченных пластических деформаций и соответствующее частичное перераспределение опорного и пролетного моментов (как для сечений 2-го класса по виду напряженно-деформированного состояния).

Наиболее простым по трудоемкости и исполнению является устройство неразрезного прогона по двухпролетной схеме. В этом случае для отправочной марки возможно использование проката стандартной длины $(12 \mathrm{M})$ и применение таких же узлов крепления прогонов к верхним поясам стропильных ферм, как при разрезной схеме (при отсутствии монтажного зазора). Экономия стали при использовании неразрезной двухпролетной схемы по сравнению с разрезной схемой расположения прогонов для покрытия проектируемого здания (пролет 30 , длина 138 , шаг ферм 6 , шаг прогонов 3 м) составляет 6624 к2.

При использовании неразрезной четырехпролетной схемы экономия стали по сравнению с разрезной схемой составляет также $6624 \kappa 2$, как при использовании двухпролетной неразрезной схемы, но с более сложным и трудоемким узлом.

Замена разрезных прогонов покрытия исследуемого сооружения неразрезными приводит к существенной экономии стали; не повышает трудоемкость работ и даже несколько упрощает монтаж при использовании двухпролетной схемы; повышает трудоемкость работ и усложняет монтаж при использовании многопролетных схем.

Ключевые слова: ферма, покрытие, балка, прогон, разрезная схема, неразрезная схема 